\title{
Effect of $2.45 \mathrm{GHz}$ microwave radiation on the fertility pattern in male mice
}

\author{
Chhoteylal Jonwal $^{1,2}$, Rashmi Sisodia ${ }^{1}$, Virender K. Saxena ${ }^{3}$ and Kavindra K. Kesari ${ }^{4,5}$ \\ ${ }^{1}$ Department of Zoology, University of Rajasthan, Jaipur, Rajasthan, India \\ ${ }^{2}$ Department of Zoology, Hindu college, Delhi University, India \\ ${ }^{3}$ Department of Physics, University of Rajasthan, Jaipur, Rajasthan, India \\ ${ }^{4}$ School of Life and Basic Sciences, Jaipur National University, Jaipur, Rajasthan, India \\ ${ }^{5}$ Department of Applied Physics, Aalto University, Espoo, Finland
}

\begin{abstract}
A number of studies have reported that male reproductive organs are susceptible to electromagnetic fields (EMFs). The aim of this study was to explore the effects of microwave radiation exposures on 6-8 weeks old male Swiss albino mice. Mice were divided into two groups: group I sham-exposed (Control), and group II - microwaves-exposed (MWs). Mice were exposed to $2.45 \mathrm{GHz}$ with power density $0.25 \mathrm{~mW} / \mathrm{cm}^{2}$ and specific absorbtion rate (SAR) $0.09 \mathrm{~W} / \mathrm{kg}$. Exposure was given in Plexiglas cages for $2 \mathrm{~h}$ /day for 30 days. Results showed that $2.45 \mathrm{GHz}$ microwave radiation resulted in a significant increase $(p<0.001)$ in catalase (CAT), malondialdehyde (MDA), reactive oxygen species (ROS) and decrease $(p<0.001)$ in the levels of glutathione peroxidase (GPx), testosterone and superoxide dismutase (SOD) $(p<0.05)$. Flow cytometer analysis of blood showed the formation of micronuclei in microwave-exposed group. Histopathological changes were also seen in seminiferous tubules of microwave-exposed group as compared to the sham-exposed group. It is concluded that $2.45 \mathrm{GHz}$ microwave radiation exposure causes oxidative stress in testes and it may lead to detrimental and injurious effects on fertility potential of the male reproductive system of Swiss albino mice.
\end{abstract}

Key words: Microwave radiation - Reactive oxygen species - Testosterone - Micronuclei - Male infertility

\section{Introduction}

Reports of declining male fertility have raised interest in assessing the role of environmental and occupational exposure to electromagnetic fields (EMFs) in the aetiology of human infertility. The sources of microwave radiation are mainly from the telecommunication networks, microwave ovens, cell phones, military and domestic applications. Leakage of EMFs radiation from such devices into the environment has posed a severe concern on human health (Khaki et al. 2008; Wang et. al. 2008; Hashem et al. 2009). The male reproductive system is highly vulnerable to physical factors and environmental assaults which may lead to various reproductive disorders like

Correspondence to: Rashmi Sisodia, Department of Zoology, University of Rajasthan, Jaipur, Rajasthan, India, 302004

E-mail: rashsisodia@yahoo.co.in testicular abnormalities, chromosomal aberrations, infertility, testicular cancer and congenital defects in offspring (Havas 2000; Kim et al. 2007). Exposure to EMFs have also shown a significant decrease in sperm parameters seminal vesicle weight, the diameter of the seminiferous tubules, sperm motility, testosterone levels and adverse histological changes in testes (Bahaodini et al. 2015; Shokri et al. 2015; Chauhan et al. 2016). Exposure to microwave radiation promotes histopathological changes in testis, diminishes testosterone levels and it stimulates clastogenic effects in male germ cells (Kumar et al. 2012b; Meena et al. 2013). Exposure to EMF can enhance reactive oxygen species (ROS) that stimulates lipid peroxidation (Kumar et al. 2011; Avendano et al. 2012; Atasoy et al. 2013). An increased level of ROS due to microwave radiation may have an adverse effect on the male reproductive system and may lead to infertility (Kesari et al. 2010, 2011; Nisbet et al. 2012). ROS may also increase the for- 
mation of micronuclei and impaired embryonic development (Kumar et al. 2010, 2011). Micronuclei are used as a sensitive predictor of the clastogenic potential of radiation-induced chromosomal damage (Criswell et al. 1998; Yoshikawa et al. 2000; McNamee et al. 2002). Some previous studies showed that chronic exposure to EMFs induces oxidative stress and reduces the total anti-oxidative capacity of testicular cells by diminishing activity of catalase (CAT) superoxide dismutase (SOD) glutathione peroxidase (GPx) and it also elevates malondialdehyde formation by lipid peroxidation (Kesari and Behari 2010; Kesari et al. 2011). The DNA integrity of male germ cells is extremely important as they pass genetic material to the next generation. Declining sperm quality and increasing infertility patterns over the decades has set the male reproductive organs as most susceptible to electromagnetic radiation. Hence the present study was designed to elucidate the effects and mechanism of microwaves radiations on male reproductive organs.

\section{Materials and Methods}

\section{Experimental animals}

Male Swiss albino mice, 6-8 weeks old, weighing $35.0 \pm$ $3.0 \mathrm{~g}$ were used for the present study. Mice were maintained in the animal house as per the norms established by Institutional Animal Ethical Committee (IAEC). The mice were housed in clean Plexiglas cages and maintained under controlled conditions of temperature with constant 12-h light and 12-h dark schedule and provided with standard mice feed (Hindustan Unilever Limited, Delhi, India) and water ad libitum. The study was approved by Departmental Ethical Committee (DEC), Department of Zoology, University of Rajasthan.

\section{Exposure chamber}

Microwave radiation experimental bench (Fig. 1) was used for the exposure of mice. The bench consisted of a signal generator, isolator, attenuator, frequency meter, horn antenna and a specially designed animal cage. Microwave power was delivered to the isolator by attenuating the power with the tunable probe connected to the frequency meter. The output power was transmitted through the horn antenna to the animal cage. A graphite sheet was used to minimize the reflection of scattered beam. A rectangular box made of Plexiglas was used to house the mice. The box was properly partitioned and well ventilated with holes of $1-\mathrm{cm}$ diameter. The dimensions of the box were made in such a way that animals stay comfortably inside the box. Total 16 mice were divided into two groups: Sham-exposed $(n=8)$, and microwave-exposed $(n=8)$ group. The mice were exposed to $2.45 \mathrm{GHz}$ microwave radiation through the horn antenna for $2 \mathrm{~h}$ /day for 30 consecutive days.

The bench was set to generate microwave radiation of $2.45 \mathrm{GHz}$ frequency. The power density $0.25 \mathrm{~mW} / \mathrm{cm}^{2}$ was measured by using the formula: $C=P_{t} \cdot G_{t} / 4 \pi R^{2}$, where, $P_{t}$ is transmitting power by the source; $G_{t}$ is transmitting antenna gain; $\mathrm{R}$ is distance between the horn antenna and mid-plane of the exposure cage. The specific absorption rate (SAR) was calculated by using the Durney equation (Durney et al. 1984). The horn antenna horizontally exposed the mice inside the Plexiglas box and power density was recorded at the center of box by a power meter (a peak sensitive device with RF power sensors 6900 series' and 'IFR 6960B RF power meter, made of Aeroflex Inc, Wichita, KS, USA). The whole-body SAR was estimated to be $0.09 \mathrm{~W} / \mathrm{kg}$. The horn antenna was kept in H-plane configuration so that electric field of the waves was perpendicular to the ground surface. The electric field in the box was almost uniform because the dimensions

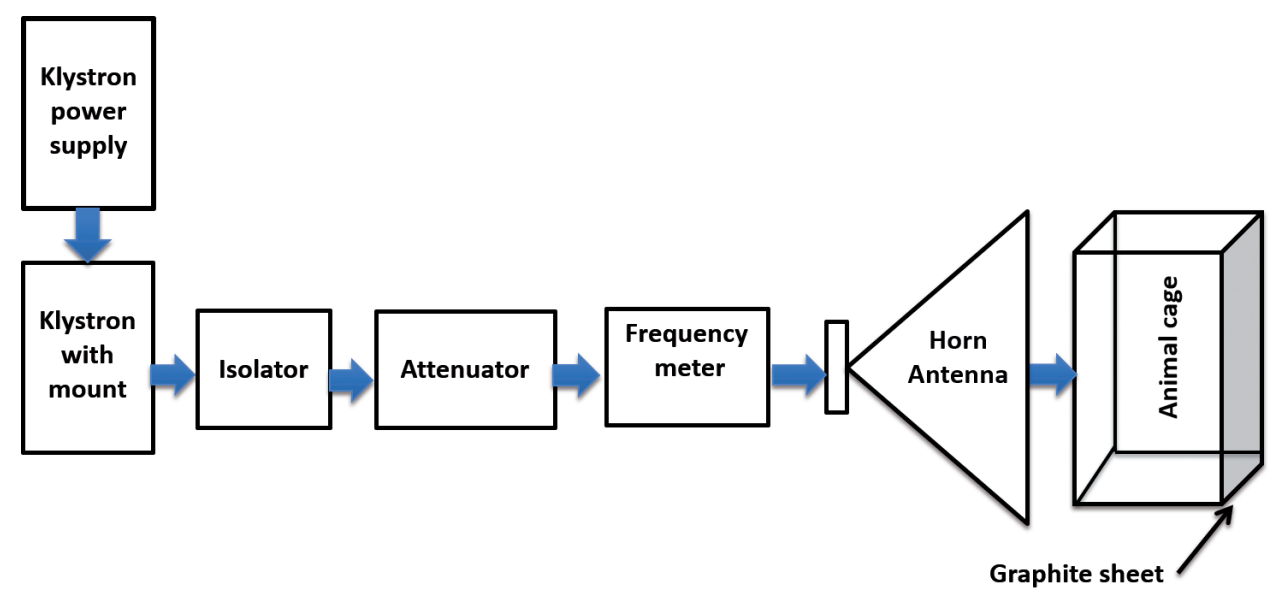

Figure 1. Schematic diagram of $2.45 \mathrm{GHz}$ microwave exposure set-up with animal cage indicating individual animal's position. 
of the box were of the order of one wavelength only. Two experimental set-ups were calibrated identically and used for exposure. Every day two mice were housed at a time in the box and the box was placed at the same location facing the horn antenna. No animal blocked the radiation falling on the other animal. The temperature in the chamber was maintained around $25-27^{\circ} \mathrm{C}$ throughout the experiment. At the end of the exposure period, mice were sacrificed and testes were quickly excised for further studies.

\section{Reactive oxygen species (ROS)}

ROS was measured by the method of Lee et al. (2006). Briefly, $50 \mathrm{mg}$ of the whole testis was homogenized in $1 \mathrm{ml}$ of PBS (0.1 $\mathrm{M} \mathrm{Na}_{2} \mathrm{HPO}_{4}, 0.1 \mathrm{M} \mathrm{KH}_{2} \mathrm{PO}_{4}, 1.37 \mathrm{M} \mathrm{NaCl}, 2.7 \mathrm{mM} \mathrm{KCl}$, pH 7.4; (Sigma-Aldrich, St. Louis, MO, USA) and filtered by passing through $100 \mu \mathrm{m}$ pore size strainer and centrifuged at $100 \times g$ for $10 \mathrm{~min}$. The pellet was re-suspended in $1 \mathrm{ml}$ of PBS and the cells were treated with $10 \mu \mathrm{l}$ of 2'7'-dichlofluorescein diacetate (3.3 $\mu \mathrm{M}$; DCFH-DA; Molecular probes, Eugene, OR, USA). The cells were incubated at room temperature (RT) for 10 minutes in dark and then centrifuged at $100 \times g$ for $10 \mathrm{~min}$. The pellet was washed in $1 \mathrm{ml}$ of PBS. Thereafter cells were examined by flow cytometry (Guava technologies, CA, USA). The results were expressed as (U/1).

\section{Malondialdehyde (MDA)}

Following the method of Buege and Aust (1978), the amount of MDA in sperm cells ( $10^{6}$ cells) was measured by monitoring the formation of thiobarbituric acid reactive substances (TBARS). The opted method was based on spectrophotometric measurement of the colour generated by the reaction of thiobarbituric acid (TBA; Sigma-Aldrich, St. Louis, MO, USA) with MDA. $2 \mathrm{ml}$ of each sample treated with trichloroacetic acid (15\% $\mathrm{w} / \mathrm{v})$ containing $1 \mathrm{mM}$ EDTA was centrifuged at $1,000 \times \mathrm{g}$ for $10 \mathrm{~min}$. The supernatant was boiled at $100^{\circ} \mathrm{C}$ in the water bath with an equal volume of TBA $(0.7 \% \mathrm{w} / \mathrm{v})$ for $20 \mathrm{~min}$, and after cooling, samples were centrifuged at $1,000 \times g$ for 10 minutes. After centrifugation, the absorbance was recorded at $532 \mathrm{~nm}$ by using Ultra Violet-Vis double beam spectrophotometer (Double Beam Spectrophotometer 2203, Systronics, Ahmedabad, Gujarat, India). A standard curve was prepared by using tetramethoxy-propane (TMP) (purchased from Himedia, Mumbai, Maharashtra, India). After comparison with a standard curve, the MDA level was expressed in $\mathrm{nmol} / 10^{6}$ sperm.

\section{Glutathione peroxidase (GPx)}

The EIA kit (catalogue No. 703102 of Cayman Chemicals Company Ann Arbor, Michigan, USA) was used for the measurement of GPx. The procedure of measurement for the assay was followed as per manufacturer manual. The wells plates were placed in micro-plate spectrophotometer reader (BioTek Instruments Winooski, Vermont, USA) and the absorbance of the samples was taken at $340 \mathrm{~nm}$. The data were expressed in $\mathrm{nmol} / \mathrm{min} / \mathrm{ml}$.

\section{Superoxide dismutase (SOD)}

Superoxide dismutase EIA kit (Catalogue No. 706002 of Cayman Chemical Company Ann Arbor, Michigan, USA) was used. The procedure of measurement for the assay was followed as per manufacturer manual. The sample plates were kept in micro-plate spectrophotometer reader and absorbance was taken at $450 \mathrm{~nm}$. The data were expressed in $\mathrm{U} / \mathrm{ml}$.

\section{Catalase (CAT)}

Catalase EIA kit (catalogue No. 707002 of Cayman Chemical Company Ann Arbor, Michigan, USA) was used. The procedure of measurement for the assay was followed as per manufacturer manual. The absorbance was measured at $540 \mathrm{~nm}$ by micro-plate reader spectrophotometer. The data were expressed in $\mathrm{nmol} / \mathrm{min} / \mathrm{ml}$.

\section{Testosterone}

Testosterone enzyme immunoassay (EIA) kit (catalogue No.582701 of Cayman Chemical Company Ann Arbor, Michigan, USA) was used to perform serum testosterone. For this, $50 \mathrm{ml}$ of testosterone standard, $50 \mathrm{ml}$ of testosterone AChE tracer and $50 \mathrm{ml}$ of testosterone antiserum were added to the wells containing $100 \mathrm{ml}$ of EIA buffer. The sensitivity of the assay was $6 \mathrm{pg} / \mathrm{ml}$. The optical density was measured at $405-420 \mathrm{~nm}$ by spectrophotometer (BioTek Instruments Winooski, Vermont, USA). The data were expressed in $\mathrm{ng} / \mathrm{ml}$.

\section{Micronucleus measurement}

Micronucleus assay was used to detect DNA damage and clastogenic effects of electromagnetic fields by providing a rapid ratio of $\mathrm{PCE} / \mathrm{NCE}$ (polychromatic erythrocyte/ normochromatic erythrocyte) percentage gated values. Micronucleus assay was performed following the method of Criswell et al. (1998) and Kumar et al. (2012b). Briefly, $1 \mathrm{ml}$ blood sample was added to $5 \mathrm{ml}$ of phosphate-buffered saline (PBS) and centrifuged at $300 \times g$ for $5 \mathrm{~min}$. The pellet was re-suspended in $1 \mathrm{ml}$ of $\mathrm{PBS}$ then $100 \mu \mathrm{l}$ of sample was mixed with $5 \mathrm{ml}$ of fixative Sorensen buffer A $\left(0.05 \mathrm{M} \mathrm{KH}_{2} \mathrm{PO}_{4}\right)$, Sorensen buffer B $\left(0.05 \mathrm{M} \mathrm{Na}_{2} \mathrm{HPO}_{4} .2 \mathrm{H}_{2} \mathrm{O}, \mathrm{pH} 6.8,30 \mu \mathrm{g} / \mathrm{ml}\right.$ SDS) and $1 \%$ glutaraldehyde (v/v) (Fisher scientific chemicals, Mumbai, India). Samples were vortexed vigorously and kept in the fixative for $5 \mathrm{~min}$ at room temperature. Thereafter, the samples were centrifuged at $300 \times g$ for $5 \mathrm{~min}$ and the pellets were re-suspended in $0.5 \mathrm{ml}$ of PBS. 
Thereafter $400 \mu \mathrm{l}$ of cold solution A $(0.1 \mathrm{ml}$ Triton X-100, $8 \mathrm{ml} 1.0 \mathrm{~N} \mathrm{HCl}, 0.877 \mathrm{~g} \mathrm{NaCl}$, and distilled water to a final volume of $100 \mathrm{ml})$ and $1.2 \mathrm{ml}$ of cold solution $\mathrm{B}(37 \mathrm{ml}$ $0.1 \mathrm{M}$ anhydrous citric acid, $63 \mathrm{ml} 0.2 \mathrm{M} \mathrm{Na}_{2} \mathrm{HPO}_{4}$ ( $\mathrm{pH}$ 6.0), $0.877 \mathrm{~g} \mathrm{NaCl}, 34 \mathrm{mg}$ EDTA disodium salt, and $0.6 \mathrm{ml}$ acridine orange $(1 \mathrm{mg} / \mathrm{ml})$ ) were added to the resuspended pellets. Samples were mixed by vortexing and kept on ice for $30 \mathrm{~min}$ in dark for the stain to appear. After staining, samples were centrifuged at $300 \times g$ for $5 \mathrm{~min}$. The supernatant was carefully removed without disturbing cellular pellet. $1 \mathrm{ml}$ of PBS was added to the pellet, resuspended, and mixed by vortexing. Thereafter samples were analyzed by Flow-cytometer. All the events were recorded on forward angle scatter (FALS, linear scale, related to cell size), side scatter (SSC, log scale, related to cellular complexity), DNA fluorescence (FL1-H log, green fluorescence, $530 \mathrm{~nm}$ ), and RNA fluorescence (FL3-H log, red fluorescence, $675 \mathrm{~nm}$ ). Analysis of micronucleus events were passed through the polychromatic erythrocyte (PCE) and normochromatic erythrocyte (NCE) population. Toxicity was detected as a decrease in the ratio of PCE/NCE.

\section{Histopathology of testis}

Testes were dissected from animals and fixed in bouin's fixative. Samples were embedded in paraffin, sectioned and stained with hematoxylin and eosin. Slides were examined by light microscopy $(40 \times 10$ magnification) to observe histopathological changes.

\section{Statistical analysis}

Data were presented as the mean \pm standard deviation (SD). Student $t$-test (two-tailed) was applied to determine significant differences between sham-exposed and microwave-exposed groups; $p<0.05$ was considered as significant difference.

\section{Results}

The microwave-exposed group showed a statistically significant $(p<0.001)$ increase in the levels of ROS (Fig. 2A) and significant $(p<0.001)$ decrease in the levels of testosterone (Fig. 2B) in comparison to the sham-exposed group (Fig. 2, Table 1). Statistically significant $(p<0.001)$ increase in the levels of MDA (Fig. 3A) and CAT (Fig. 3B) was measured in the microwave-exposed group in comparison to the shamexposed group. However, statistically significant decrease $(p<0.001)$ in the levels of GPx (Fig. 3C) and SOD $(p<0.05)$ (Fig. 3D) was measured in microwave-exposed group in comparison to the sham-exposed ones. The measurement of micronuclei formation was recorded by flow cytometer (Fig. 4A,B), where the rapid ratio of PCE/NCE percentage
Table 1. Variations in the endpoints after $2.45 \mathrm{GHz}$ microwave exposure

\begin{tabular}{lcc}
\hline Biochemical parameters & Sham-exposed & $\begin{array}{c}\text { Microwave- } \\
\text { exposed }\end{array}$ \\
\hline ROS $(\mathrm{U} / \mathrm{l})$ & $14.7 \pm 0.83$ & $27.23 \pm 1.64^{* *}$ \\
MDA $\left(\mathrm{nmol} / 10^{6}\right.$ sperm) & $0.11 \pm 0.03$ & $0.19 \pm 0.05^{* *}$ \\
GPx $(\mathrm{nmol} / \mathrm{min} / \mathrm{ml})$ & $11.67 \pm 0.91$ & $4.73 \pm 0.68^{* *}$ \\
SOD $(\mathrm{U} / \mathrm{ml})$ & $42.56 \pm 3.96$ & $18.85 \pm 1.78^{*}$ \\
CAT $(\mathrm{nmol} / \mathrm{min} / \mathrm{ml})$ & $21.43 \pm 1.67$ & $45.85 \pm 2.97^{* *}$ \\
Testosterone $(\mathrm{ng} / \mathrm{ml})$ & $4.02 \pm 0.31$ & $1.95 \pm 0.49^{* *}$ \\
Micronuclei formation & $1.56 \pm 0.22$ & $0.73 \pm 0.04^{* *}$ \\
\hline
\end{tabular}

Data are presented as the mean $\pm \mathrm{SD}$; ${ }^{\star} p<0.05$ (significant), ${ }^{* *} p<0.001$ (highly significant) vs. sham-exposed group. ROS, reactive oxygen species; MDA, malondialdehyde; GPx, glutathione peroxidase; SOD, superoxide dismutase; CAT, catalase.

gated value of $2.45 \mathrm{GHz}$ exposed group showed a statistically significant $(p<0.001)$ decrease in comparison to the shamexposed group. (Fig. 4, Table 1).

Results observed for the histopathology of testis showed abnormal spermatogenic cycle, irregular epithelial lining, detachment between the adjacent seminiferous tubules, occlusion of the lumen of seminiferous tubules, large vacuoles and condensed nuclei in some cells of microwave-exposed group (Fig. 5B) in comparison to the sham-exposed group (Fig. 5A).
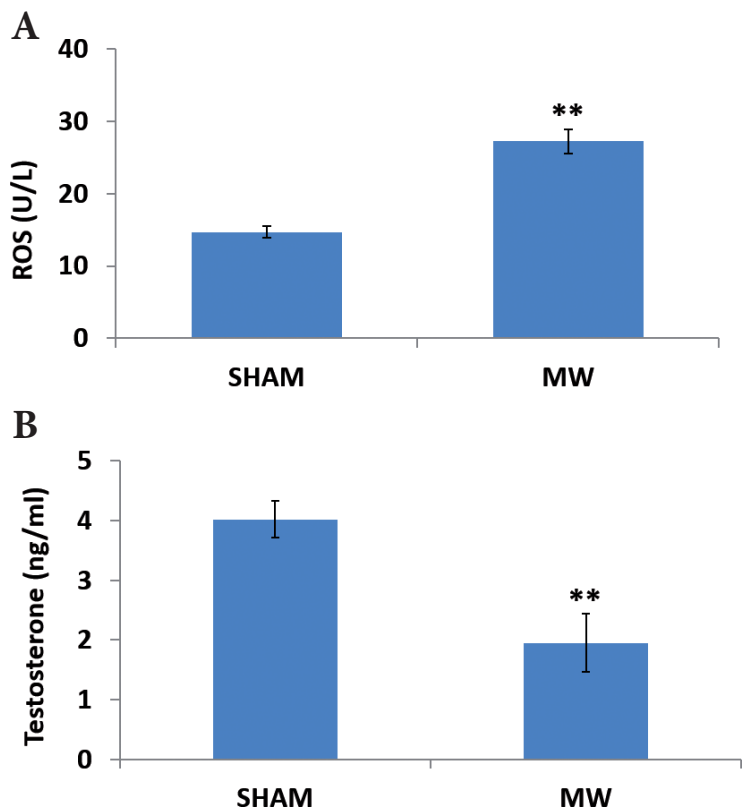

Figure 2. The effects of $2.45 \mathrm{GHz}$ microwave radiation on the levels of reactive oxygen species (ROS, $\mathbf{A}$ ) and testosterone $(\mathbf{B})$ in testis of Swiss albino mice. The values are means $\pm \mathrm{SD} ;{ }^{* *} p<0.001 v s$. sham-exposed group. MW, microwave-exposed group. 

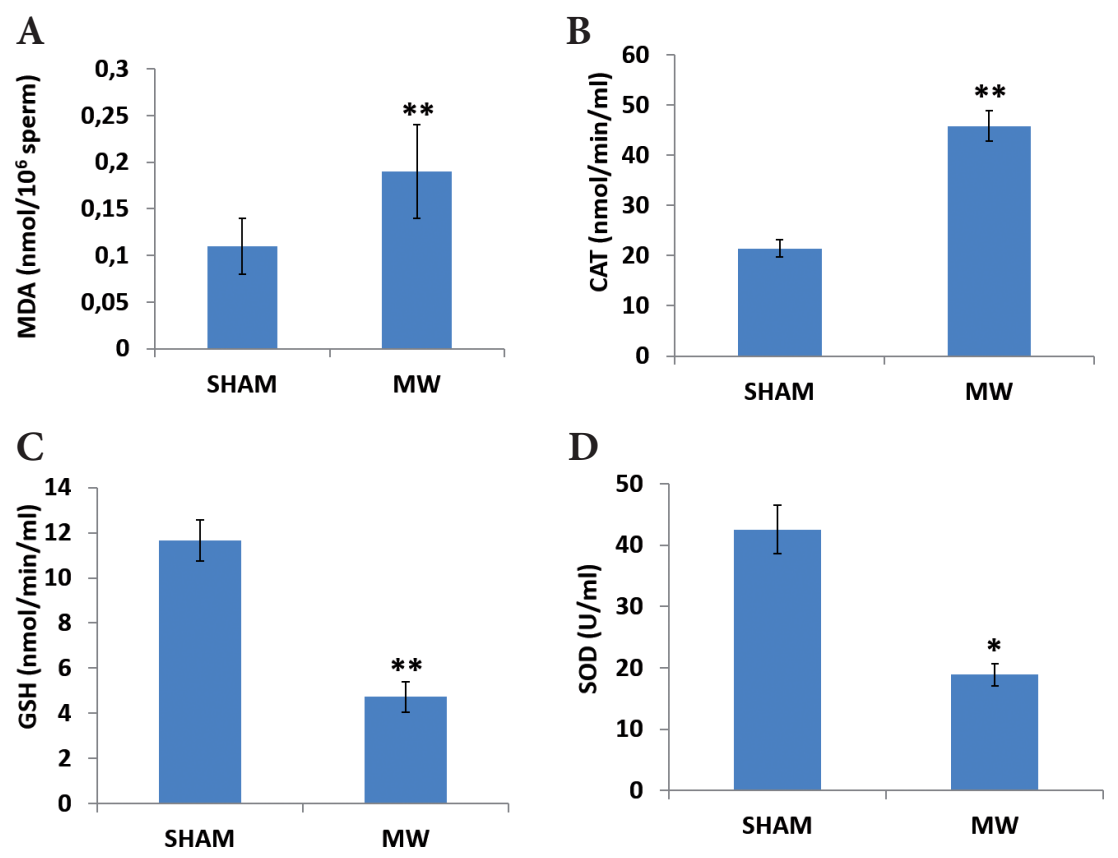

Figure 3. The effects of $2.45 \mathrm{GHz}$ microwave radiation on malondialdehyde (MDA, A), catalase (CAT, B), glutathione peroxidase $(\mathrm{GPx}, \mathrm{C})$ and superoxide dismutase (SOD, D) levels in testis of Swiss albino mice. The values are in means $\pm \mathrm{SD} ;{ }^{* *} p<0.001$, ${ }^{*} p<0.05$ vs. sham-exposed group. MW, microwave-exposed group.

\section{Discussion}

The present investigations provide several important findings related to biochemical, pathophysiology and clastogenic effects of $2.45 \mathrm{GHz}$ microwave radiation on the male reproductive system of mice. The findings in this study are associated with significant changes in histopathology and oxidative damage in testes through altered anti-oxidative parameters after microwave exposure of 30 days ( $2 \mathrm{~h}$ /day). The present study revealed that microwaves induce oxidative damage biochemically as evident by decreased levels of GPx, SOD and testosterone and increased levels of MDA and CAT. Our
A

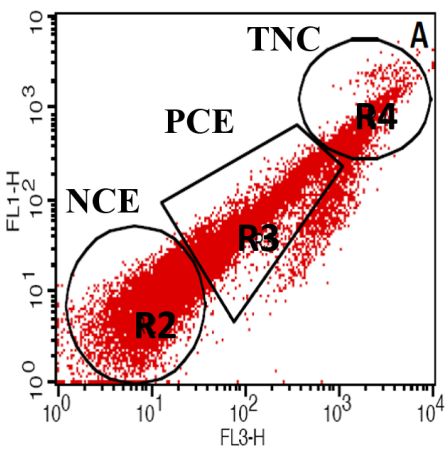

B

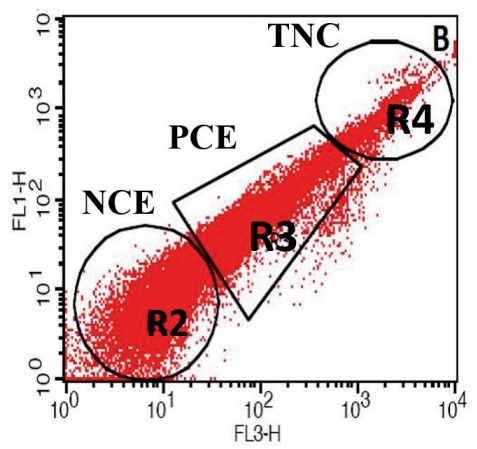

C

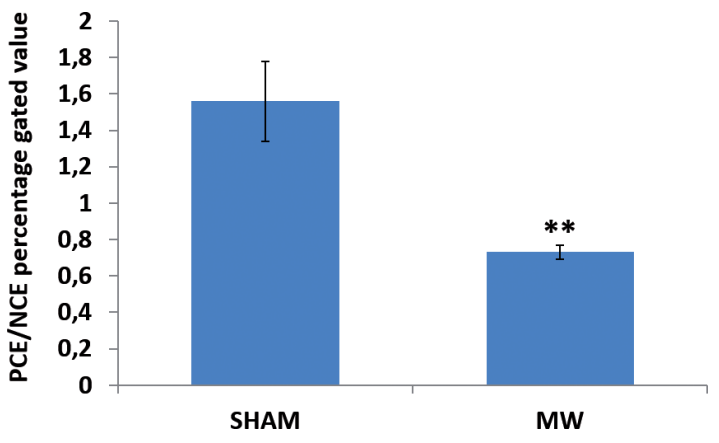

Figure 4. Micronucleus test results showing the ratio of polychromatic erythrocytes to normochromatic erythrocytes (PCE/NCE) in blood samples of mice from sham-exposed (A) and electromagnetic field-exposed (B). PCE/NCE was calculated to find out the clastogenic effect of electromagnetic fields. R2 indicates NCE, R3 indicates PCE, R4 indicates total nucleated cells (TNC). The effects of $2.45 \mathrm{GHz}$ microwave radiation on micronuclei formation $\mathrm{PCE} / \mathrm{NCE}, \%$ gated value $(\mathrm{C})$ in blood of Swiss albino mice. The values are means $\pm \mathrm{SD}$; ${ }^{* *} p<0.001 v s$. sham-exposed group. MW, microwave-exposed group. 
results are in the line of earlier findings (Shang et al. 2004; Kesari et al. 2010; Kumar et al. 2012a, 2012b; Bahaodini et al. 2015). Antioxidants play an important role to protect the cells from oxidative damage. Cellular antioxidants like SOD, GSH, Catalase and LPO are important markers of free radical generation. An adequate level of cellular antioxidants maintains the free radicals scavenging potential in testes. The authors observed an increase in CAT activity, which suggests high levels of $\mathrm{H}_{2} \mathrm{O}_{2}$ in the testicular cells (Condell et al. 1993). Free radicals are produced continuously and detoxified by SOD, GPx and CAT. With excessive free radical production and the resulting consumption of antioxidants, endogenous defense mechanisms become insufficient. This leads to decreased activity of SOD and GPx in response to electromagnetic field exposure (Amara et al. 2006). In the present study, significant changes were also observed in testosterone levels after microwave exposure. These changes might be because of overproduction of ROS and interaction between EMFs radiation and testicular cells. The ROS-induced interaction between EMF and testicular cells affect the functioning of the testes adversely. The inadequate polarization of cellular membrane is responsible for the process of various abnormalities of testosterone synthesis and secretion which may impair spermatogenesis and ultimately become a cause of infertility (Meo et al. 2010). ROS and free radicals are generated in the cells by energy transfer or by electron transfer reactions induced by EMFs exposure. During this process, a highly reactive singlet oxygen atom is formed which results in the sequential reduction to various molecules of the cell such as superoxide, hydrogen peroxide, and hydroxyl radicals (Georgiou 2010). EMFs affect spermatogenesis and testicular function through defects in the male germ line, decreased sperm count, narrower seminiferous tubules and reduction in intrascrotal testosterone levels (Dasdag et al. 1999). In agreement with the present study, EMFs exposure resulted in deceleration of spermatogenesis, disorders in germinal cell distribution, reduction in germ cell population and decrease in epithelium thickness and diameter of seminiferous tubules (Dasdag et al. 1999, 2003; Ozguner et al. 2005; Aydin et al. 2007; Rajaei et al. 2009; Khayyat 2011). The light microscopic examination of the testes sections in exposed group revealed abnormal spermatogenic cycle, irregular epithelial lining, detachment between the adjacent seminiferous tubules, occlusion of the lumen of seminiferous tubules and large vacuoles and condensed nuclei in some cells (Fig. 5B) in comparison to the control mice testes with normal spermatogenic cycle, germ cells and Sertoli cells (Fig. 5A). Therefore, it may be suggested that abnormalities in testicular morphology may be due to susceptible nature of testes towards microwave radiation. Increased level of LPO induces cellular injury in the spermatozoa due to leakage of sperm membrane fluidity (Aitken et al. 1994). Since mammalian sperm membranes contain a high level of unsaturated fatty acids and are also sensitive to oxygen-induced damage mediated by lipid peroxidation and free water-induced oxygen (Russo et al. 2006). De Iuliis et al. (2009) found that radiofrequency exposure enhances
A

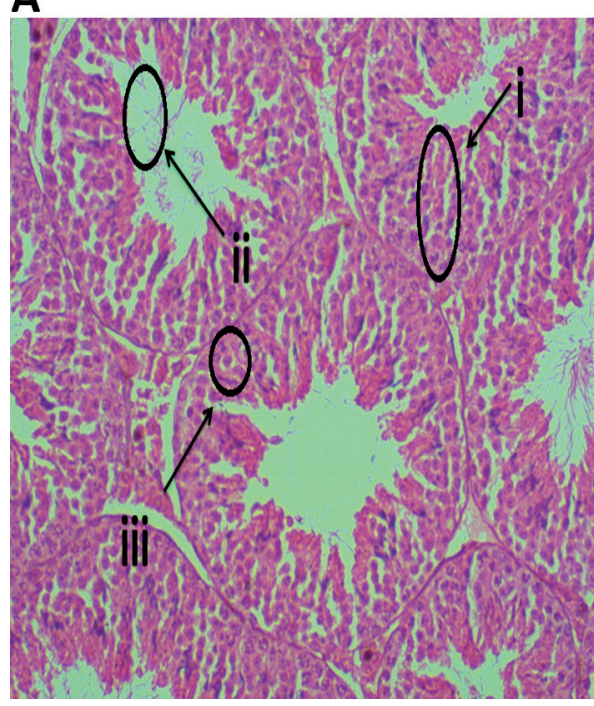

B

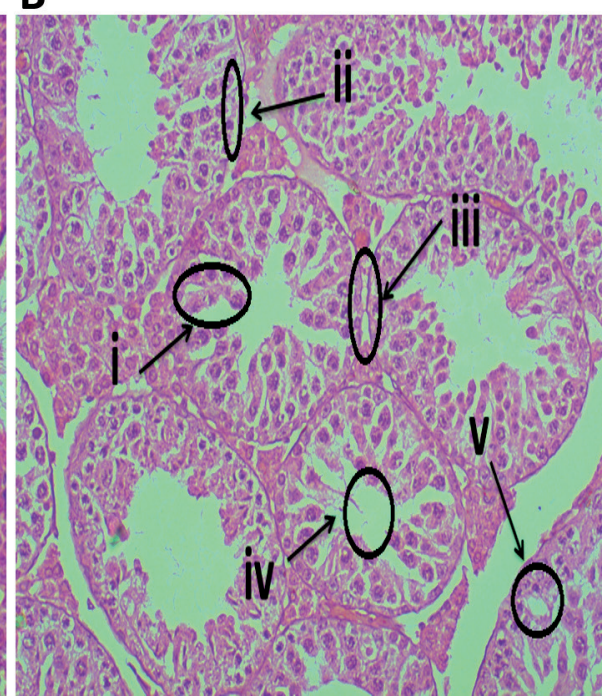

Figure 5. The light microscope examination of transverse section of sham-exposed mice testis stained with HE stain (A) shows normal spermatogenic cycle (i), germ cells (ii), sertoli cells (iii) (40×10 magnification). The light microscope examination of transverse section of mice testis exposed to $2.45 \mathrm{GHz}$ and stained with $\mathrm{HE}$ stain (B) shows abnormal spermatogenic cycle (i), irregular epithelial lining (ii), detachment between the adjacent seminiferous tubules (iii), occlusion of the lumen of seminiferous tubules (iv), large vacuoles and condensed nuclei in some cells (v) $(40 \times 10$ magnification). 
mitochondrial ROS around spermatozoa, which reduces both their motility and vitality and promotes DNA fragmentation. EMFs exposure induces oxidative stress, which may lead to DNA damage and micronuclei formation. Our study is in corroboration with the findings of earlier studies (Aweda et al. 2002; Kesari et al. 2010). The main reason for micronuclei formation is that the fragments, which are lost during cell division, cannot be segregated from the metaphase plate to either of the poles. Our results are in support of the fact that microwave radiation may be a causative factor for male infertility because it affects anti-oxidants activities and causes histopathological changes in testes. Hence it may lead to DNA damage and micronuclei formation, which may further be a cause of male infertility.

\section{Conclusion}

We conclude that microwaves at $2.45 \mathrm{GHz}$ frequency adversely affect the testicular functions and reproductive patterns by induction of oxidative stress-mediated cellular toxicity. The present study concludes that EMFs may lead to elevated oxidative stress, formation of micronuclei, decrease in testosterone levels, compromised antioxidant activities and increase in MDA levels. Histological changes in testicular tissues also revealed that microwave exposure has causative effect on fertility patterns. Results from this study also revealed important implications of microwave exposure on the male reproductive health. As a consequence of increase in free radicals and ROS, microwaves-induced oxidative stress resulted in increased ROS level, which indicates the possibility of infertility. The available evidence indicates that a very limited research has been reported on protective measures against microwave radiation induced adverse effects. This further worsens the problem of EMFs generated health problems including increased rates of male infertility. Therefore, further studies are needed to elaborate the molecular mechanism of cellular level damage in testes exposed to microwave radiation and the protective measures against adverse effects of microwave radiation should also be explored.

Acknowledgement. The authors are thankful to Department of Physics, University of Rajasthan, Jaipur for providing microwave exposure facility.

Conflict of interest. The authors report no conflict of interest.

\section{References}

Aitken J, Krausz C, Buckingham D (1994): Relationship between biochemical markers for residual sperm cytoplasm, reactive oxygen species generation, and the presence of leucocytes and precursor germ cell in human sperm suspensions. Mol. Reprod. Dev. 39, 268-279

https://doi.org/10.1002/mrd.1080390304

Amara S, Abelmelek H, Garrel C, Guiraud P, Douki T, Ravanat JL, Favier A, Sakly M, Ben Rhouma K (2006): Effects of subchronic exposure to static magnetic field on testicular function in rats. Arch. Med. Res. 37, 947-952

https://doi.org/10.1016/j.arcmed.2006.06.004

Atasoy HI, Gunal MY, Atasoy P, Elgun S, Bugdayci G (2013): Immunohisto-pathologic demonstration of deleterious effects on growing rat testes of radiofrequency waves emitted from conventional Wi-Fi devices. J. Pediatr. Urol. 9, 223-229 https://doi.org/10.1016/j.jpurol.2012.02.015

Avendano C, Mata A, Sarmiento SCA, Doncel GF (2012): Use of laptop computers connected to internet through Wi- Fi decreases human sperm motility and increases sperm DNA fragmentation. Fertil. Steril. 97, 39-45 https://doi.org/10.1016/j.fertnstert.2011.10.012

Aweda MA, Gbenebitse S, Meidinyo RO (2002): Effects of $2.45 \mathrm{GHz}$ microwave exposures on the peroxidation status in Wistar rats. Niger Postgrad. Med. J. 10, 243-246

Aydin M, Turk G, Yuksel M, Cevik A, Apaydin A, Yilmaz S (2007): Effect of electromagnetic field on the sperm characteristics and histopathological status of testis in rats. Med. Weter. 63, 178-183

Bahaodini A, Owjfard M, Tamadon A, Jafari SM (2015): Low frequency electromagnetic fields long-term exposure effects on testicular histology, sperm quality and testosterone levels of male rats. APJR 4, 195-200 https://doi.org/10.1016/j.apjr.2015.06.001

Buege JA, Aust SD (1978): Methods in Enzymology. Vol. 52, pp. 302-314, Academic Press, New York https://doi.org/10.1016/S0076-6879(78)52032-6

Chauhan P, Verma HN, Sisodia R, Kesari KK (2016): Microwave radiation $(2.45 \mathrm{GHz})$-induced oxidative stress: Whole-body exposure effect on histopathology of Wistar rats. Electromagn. Biol. Med. 36, 20-30 https://doi.org/10.3109/15368378.2016.1144063

Condell RA, Tappel AL (1993): Evidence for suitability of glutathione peroxidase as a protective enzyme: Studies of oxidative damage, restoration and proteolysis. Arch. Biochem. Biophys. 223, 407 https://doi.org/10.1016/0003-9861(83)90604-5

Criswell KA, Krishna G, Zielinski D, Urda GA, Theiss JC, Juneau P, Bleavins MR. (1998): Use of acridine orange in: Flow cytometric assessment of micronuclei induction. Mutat. Res. 414, 63-75 https://doi.org/10.1016/S1383-5718(98)00042-4

Dasdag S, Ketani MA, Akdag Z, Ersay AR, Sari I, Demirtas OC, Celik MS (1999): Whole-body microwave exposure emitted by cellular phones and testicular function of rats. Urol. Res. 27, 219-223 https://doi.org/10.1007/s002400050113

Dasdag S, Akdag MZ, Aksen F, Yilmaz F, Bashan M, Dasdag MM, Celik MC (2003): Whole body exposure of rats to microwaves emitted from a cell phone does not affect the testes. Bioelectromagnetics 24, 182-188 https://doi.org/10.1002/bem.10083

De Iuliis GN, Newey RJ, King BV, Aitken RJ (2009): Mobile phone radiation induces reactive oxygen species production and DNA damage in human spermatozoa in vitro. PLoS ONE 4, e6446 
https://doi.org/10.1371/journal.pone.0006446

Durney CH, Iskander MF, Massoudi H, Johnson CC (1984): An empirical formula for broadband SAR calculations of prolate spheroidal models of humans and animal. In: Biological Effects of Electromagnetic Radiation. (Ed. Osepchuk JM), pp. 85-90, IEEE Press, New York

Georgiou CD (2010): Oxidative stress-induced biological damage by low-level EMFs: mechanisms of free radical pair electron spin-polarization and biochemical amplification. In: NonThermal Effects and Mechanisms of Interaction between Electromagnetic Fields and Living Matter. (Eds. Giuliani L, Soffritti M), pp. 66-113, Ramazzini Institute European J. Oncol. Lib.

Hashem MA, El-Sharkawy NI (2009): Hemato-biochemical and immunotoxicological effects of low electromagnetic field and its interaction with lead acetate in mice. Iraq. J. Vet. Sci. 23, 105-114

Havas M (2000): Biological effects of non-ionizing electromagnetic energy: A critical review of the reports by the US National Research Council and the US National Institute of Environmental Health Sciences as they relate to the broad realm of EMF bio effects. Environ. Rev. 8, 173-253 https://doi.org/10.1139/a00-004

Kesari KK, Behari J (2010). Microwave exposure affecting reproductive system in male rats. Appl. Biochem. Biotechnol. 162, 416-428 https://doi.org/10.1007/s12010-009-8722-9

Kesari KK, Kumar S, Behari J (2010): Mobile phone usage and male infertility in Wistar rats. Indian J. Exp. Biol. 48, 987-992

Kesari KK, Kumar S, Behari J (2011): Effects of radiofrequency electromagnetic waves exposure from cellular phone on reproductive pattern in male Wistar rats. Appl. Biochem. Biotechnol. 164, 546-559 https://doi.org/10.1007/s12010-010-9156-0

Kesari KK, Behari J (2012): Evidence for mobile phone radiation exposure effects on reproductive pattern of male rats: Role of ROS. Electromagn. Biol. Med. 31, 213-222 https://doi.org/10.3109/15368378.2012.700292

Khaki AF, Zarrintan S, Khaki A, Zahedi A (2008): The effects of electromagnetic field on the microstructure of seminal vesicles in rat: A light and transmission electron microscope study. Pak. J. Biomed. Sci. 11, 692-701 https://doi.org/10.3923/pjbs.2008.692.701

Khayyat LI (2011): The histopathological effects of an electromagnetic field on the kidney and testis of mice. Eurasia J. Biosci. 5, 103-109 https://doi.org/10.5053/ejobios.2011.5.0.12

Kim JY, Kim HT, Moon KH, Shin HJ (2007): Long-term exposure of rats to a $2.45 \mathrm{GHz}$ electromagnetic field: Effects on reproductive function. Korean J. Urol. 48, 1308-1314 https://doi.org/10.4111/kju.2007.48.12.1308

Kumar S, Kesari KK, Behari J (2010): Evaluation of genotoxic effects in male wistar rats following microwave exposure. Ind. J. Exp. Biol. 48, 586-592

Kumar S, Kesari KK, Behari J (2011): The therapeutic effect of a pulsed electromagnetic field on the reproductive patterns of male Wistar rats exposed to a $2.45-\mathrm{GHz}$ microwave field. Clinics (Sao Paulo) 66, 1237-1245 https://doi.org/10.1590/S1807-59322011000700020

Kumar S, Behari J, Sisodia R (2012a): Impact of Microwave at XBand in the aetiology of male infertility. Electromagn. Biol. Med. 31, 223-232 https://doi.org/10.3109/15368378.2012.700293

Kumar S, Behari J, Sisodia R (2012b): Influence of electromagnetic fields on reproductive system of male rats. Electromagn. Biol. Med. 89, 147-154

Lee KS, Kim SR, Park SJ, Min KH, Lee KY, Jin SM, Yoo WH, Lee YC (2006): Antioxidant down regulates interleukin-18 expression in asthma. Mol. Pharmacol. 70, 1184-1193 https://doi.org/10.1124/mol.106.024737

McNamee JP, Bellier PV, Gajda GB, Miller SM, Lemay EP, Lavallee BF, Marro L, Thansandote A (2002): DNA damage and micronucleus induction in human leukocytes after acute in vitro exposure to a $1.9 \mathrm{GHz}$ continuous-wave radiofrequency field. Radiat. Res. 158, 523-533

https://doi.org/10.1667/0033-7587(2002)158[0523:DDAMII]2.0.CO;2

Meena R, Kumari K, Kumar J, Paulraj R, Verma HN, Kavindra KK (2013): Therapeutic approaches of melatonin in microwave radiations-induced oxidative stress-mediated toxicity on male fertility pattern of Wistar rats. Electromagn. Biol. Med. 1536, 8386

Meo SA, Al-Dress AM, Hussain S, Khan MM, Imran MB (2010): Effects of mobile phone radiation on serum testosterone in Wistar albino rats. Saudi. Med. 31, 869-973

Nisbet H, Nisbet CO, Akar A, Cevik M, Karayigit MO (2012): Effects of exposure to electromagnetic field $(1.8 / 0.9 \mathrm{GHz})$ on testicular function and structure in growing rats. Res. Veterin. Sci. 93, 1001-1005 https://doi.org/10.1016/j.rvsc.2011.10.023

Ozguner M, Koyu A, Cesur G, Urtal M, Ozguner F, Gokcimen A, Delibas N (2005): Biological and morphological effects on the reproductive organs of the rats after exposure to electromagnetic fields. Saudi. Med. J. 26, 405-410

Rajaei F, Mahdi F, Nazem G, Sarreshtehdari M, Gheybi NA, Sahneh SM (2009): Effect of electromagnetic field on mice epididymis and vas deferen-A morphometric study. J. Gorgan. Univ. Med. Sci. 11, 1-7

Russo A, Troncoso N, Sanchez F, Vanella A (2006): Propolis protects human spermatozoa from DNA damage caused by benzopyrene and exogenous reactive oxygen species. Life Sci. 78, 1401-1406 https://doi.org/10.1016/j.lfs.2004.10.085

Shang X, Huang Y, Ye Z, Yu X, Gu W (2004): Protection of melatonin against damage of sperm mitochondrial function induced by reactive oxygen species. Zhonghua Nan Ke Xue 10, 604-607 (in Chinese)

Shokri S, Soltani A, Kazemi M, Sardari D, Mofrad FB (2015): Effects of Wi-Fi $(2.45 \mathrm{GHz})$ exposure on apoptosis, sperm parameters and testicular histomorphometry in rats: A time course study. Cell J. 17, 322-331

Wang XW, Ding GR, Shi CH, Zhang J, Zeng LH, Guo GH (2008): Effect of electromagnetic pulse exposure on permeability of blood testicle barrier in mice. Biomed. Environ. Sci. 21, 218-221 https://doi.org/10.1016/S0895-3988(08)60032-X

Yoshikawa T, Tanigawa M, Tanigawa T, Imai A, Hongo H, Kondo M (2000): Enhancement of nitric oxide generation by low frequency electromagnetic field. Pathophysiology 7, 131-135 https://doi.org/10.1016/S0928-4680(00)00040-7

Received: June 25, 2017

Final version accepted: November 22, 2017 